\title{
Exploring non-urban society in the Mediterranean: hill-forts, villages and sanctuary sites in ancient Samnium, Italy
}

\author{
Tesse D. Stek ${ }^{*}$
}

The Tappino Area Archaeological Project combines remote sensing, intensive survey methods and excavation to illuminate the development and working of ancient society in the Apennine Mountains, southern Italy.

The Tappino Area Archaeological Project (TAAP) studies ancient society in the area surrounding the Tappino River Valley in southern Italy (modern Molise) (Figure 1). In this mountainous landscape, human settlement developed along different trajectories than those on the urbanised coastal plains. The inland polities—usually referred to collectively as Samnites - could, however, field a formidably large army to oppose the expanding Roman Empire during the fourth to first centuries BC (Livy, History of Rome 4.8-10; Foster 1922; cf. Oakley 1997). The nature of these resilient non-urban polities sparks curiosity, as societal success and high population densities in the ancient world are usually associated with urbanism (see Dench 1995; Morgan 2003). Scepticism about the apparent level of sociopolitical complexity present in this non-urbanised area has even led to questioning the accuracy of Roman sources concerning Samnium's military power. The alternative optionthat a non-urban societal model such as Samnium's could be successful in its own rightneeds further testing, and archaeology is well positioned to attempt this. The previous Sacred Landscape Project (SLP 2004-2010) investigated the potential role of sanctuaries in such a non-urban settlement configuration. By pedestrian field surveys, the SLP contextualised the sanctuaries of Colle Rimontato, San Giovanni in Galdo and Cupa, Gildone, in their local and regional settlement organisation (cf. Di Niro \& Petrone 1993). On the basis of these surveys, several theories about the function and positioning of rural sanctuaries could be tested (cf. Stek 2009: Chapter 4 for these models). The SLP concluded that the cult places were not isolated special-purpose sites, but rather, focal points of rural communities that 'clustered' around the sanctuary, and in farms and villages (Pelgrom \& Stek 2010).

Many questions remain, however. To what extent was high site density-and thus presumably a dense ancient population-limited to areas with cultic sites? Did sanctuaries 'attract' settlement, or was the landscape overall densely settled? What are the effects of,

* Faculty of Archaeology, Leiden University, Einsteinweg 2, 2333CC Leiden, the Netherlands (Email: t.d.stek@arch. leidenuniv.nl) 


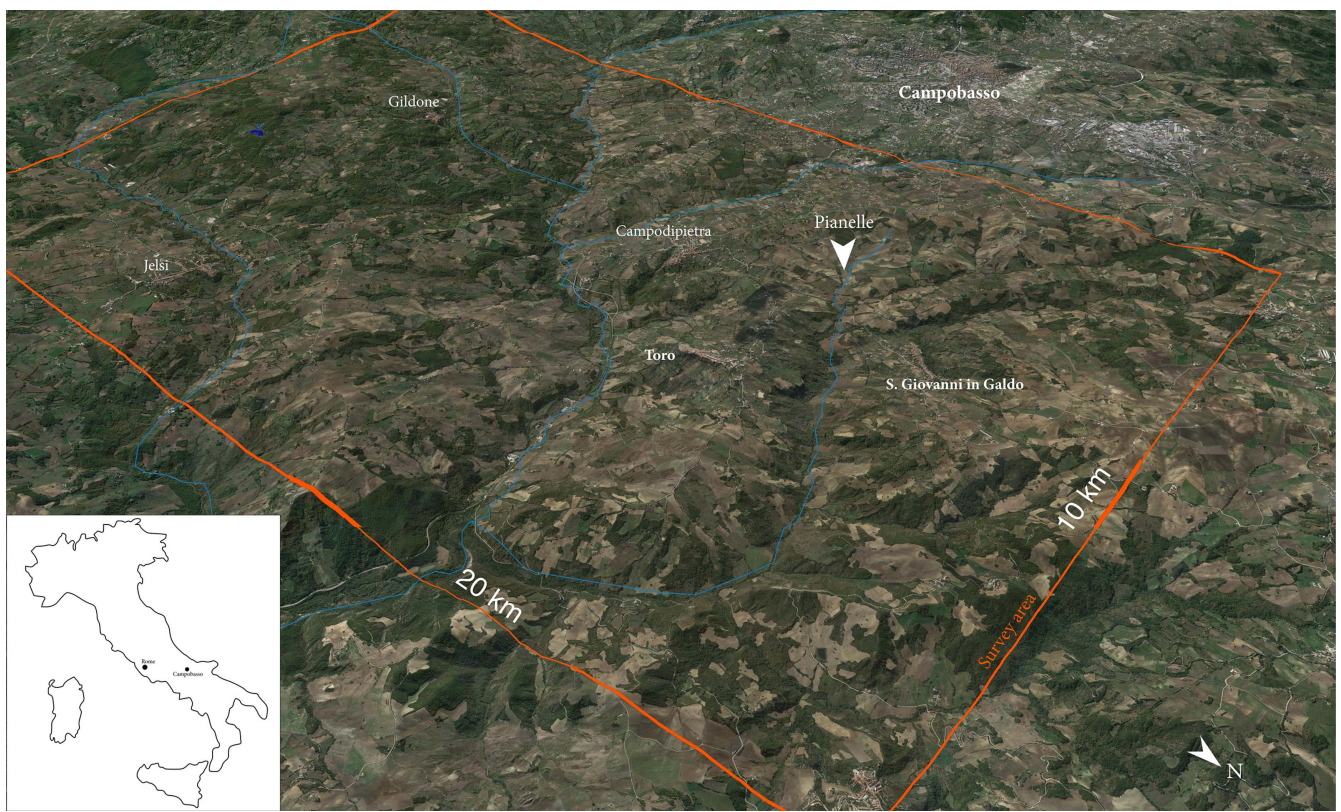

Figure 1. The research area in the Upper Tappino Valley, approximately $20 \times 10 \mathrm{~km}$ (image by A. Hamel).

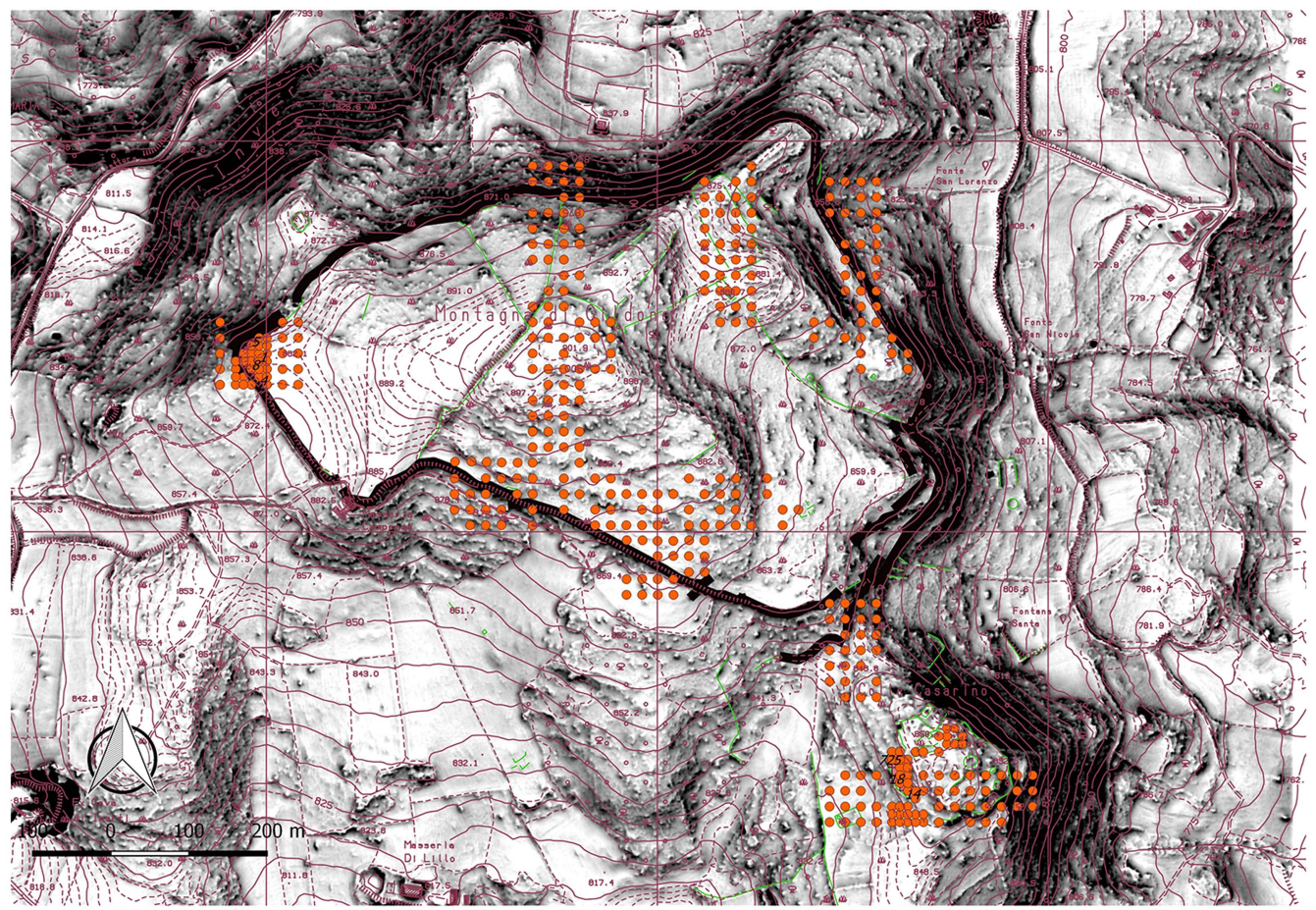

Figure 2. LiDAR rendering of the hill-fort of Montagna di Gildone, with point samples in red (image by J. Garcia Sánchez).

(C) Antiquity Publications Ltd, 2018 
amongst others, erosion, alluviation and present land-use on the detection of ancient sites by field archaeologists? What was the role of other large sites, such as villages and hilltop sites? What could all this mean for current demographic reconstructions and historical scenarios? As archaeological sites in mountainous areas are notoriously difficult to access, addressing such questions requires highly intensive field approaches and the painstaking study of finds, with usually few chronological anchors.

The TAAP applies such an intensive, holistic archaeological approach to contextualise, both spatially and chronologically, sanctuaries, hillforts and other sites in the area with greater precision. First, the plausibility of the proposed, 'clustered' model of settlements associated with sanctuary sites is tested. Second, the project aims to improve our understanding of the character of newly discovered surface sites, by intensifying intra-site surface analysis and excavation. Third, the project develops methods and field tests to compare different survey methods, and to enable the integration of different (legacy) datasets in Molise, especially the Biferno, San Vincenzo and Aesernia projects (Barker 1995; Bowes et al. 2006; Stek et al. 2015). Altogether, the project aims to compare and combine the different elements and connections that constituted local ancient societies, and seeks to strengthen the dataset sufficiently to engage in comparative studies with other Italian and Mediterranean areas.

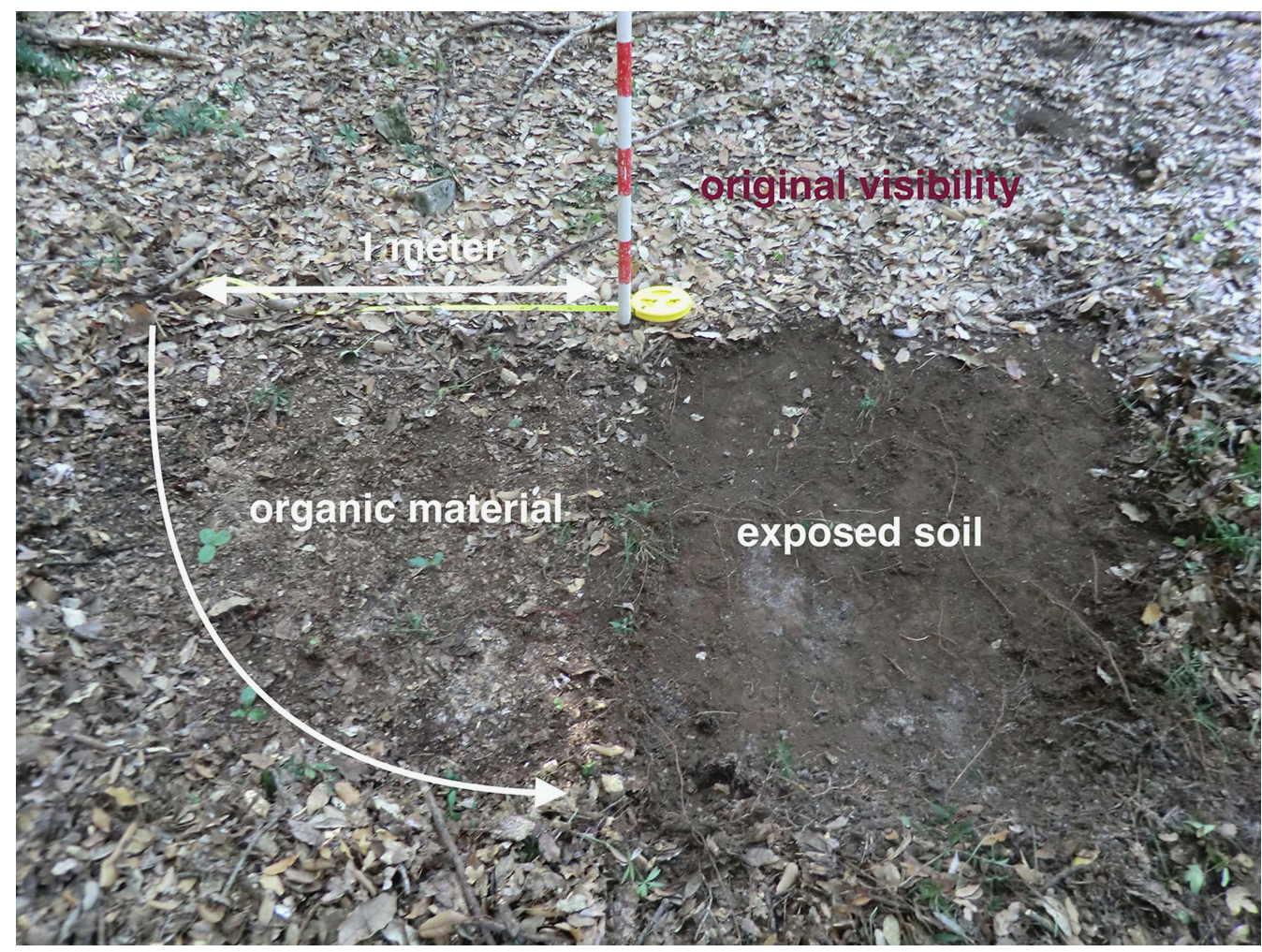

Figure 3. Point sampling as a method to sample large rural sites with variable ground visibility caused, for example, by thick vegetation or organic material in non-agricultural, forested areas (image by J. Garcia Sánchez).

(C) Antiquity Publications Ltd, 2018 


\section{Methods and results}

Our methods include field survey, excavation and remote-sensing techniques. We tested the 'cluster hypothesis' by surveying a statistically significant portion of different types of landscape and geology, including areas that are normally omitted from analysis for reasons of visibility, accessibility and expected absence of archaeological remains. Blocks of $1 \times 1 \mathrm{~km}$ were surveyed as completely as possible by 'off-site', full-collection survey, in which all accessible fields were surveyed with teams of 5-6 archaeologists walking $10 \mathrm{~m}$ apart and collecting all finds in a $2 \mathrm{~m}$-wide strip. Field surveys often focus on agricultural areas for reasons of visibility, accessibility and efficiency (Alcock \& Cherry 2004; Attema et al. 2011). To gain a better understanding of those portions of the landscape that are thus usually skipped, such as hilltops or other areas with thick vegetation, we used LiDAR data and applied point sampling after superficial topsoil cleaning. Thus, we detected, for example, various hidden sites at the Montagna di Gildone hillfort and a large Classical/Roman site at Colle S. Martino, Jelsi (Figure 2).

Point sampling is effective for large sites due to its high spatial control (Figure 3). It forms a (cost-) effective approach, particularly when combined with imagery from drones and geophysical data (Figure 4). Two rural sites that we excavated-S. Giovanni in Galdo and at Gildone-yielded not only new information about the surviving structures, but also about

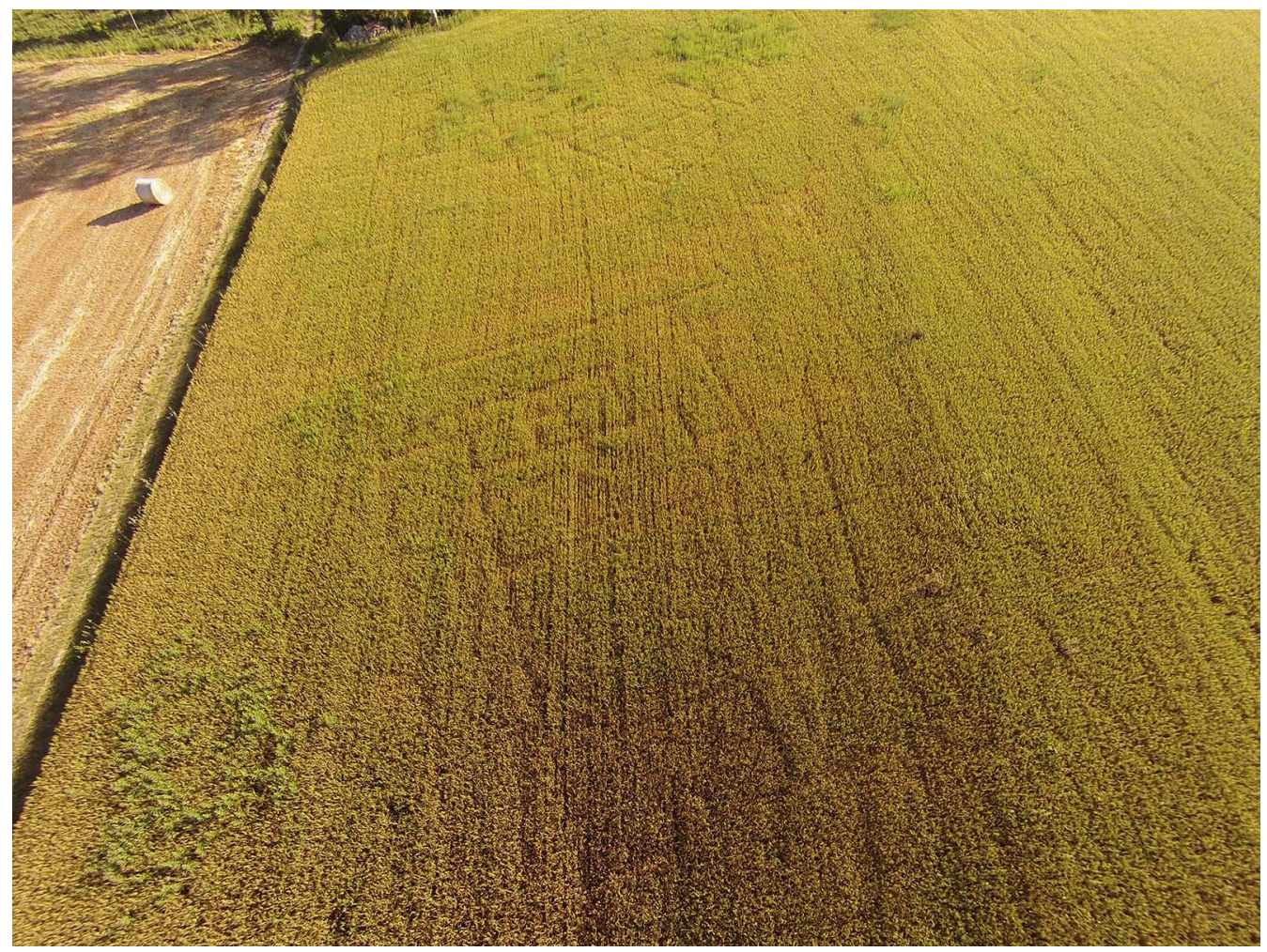

Figure 4. Drone picture of the Le Pianelle site (image by T.D. Stek).

(C) Antiquity Publications Ltd, 2018 


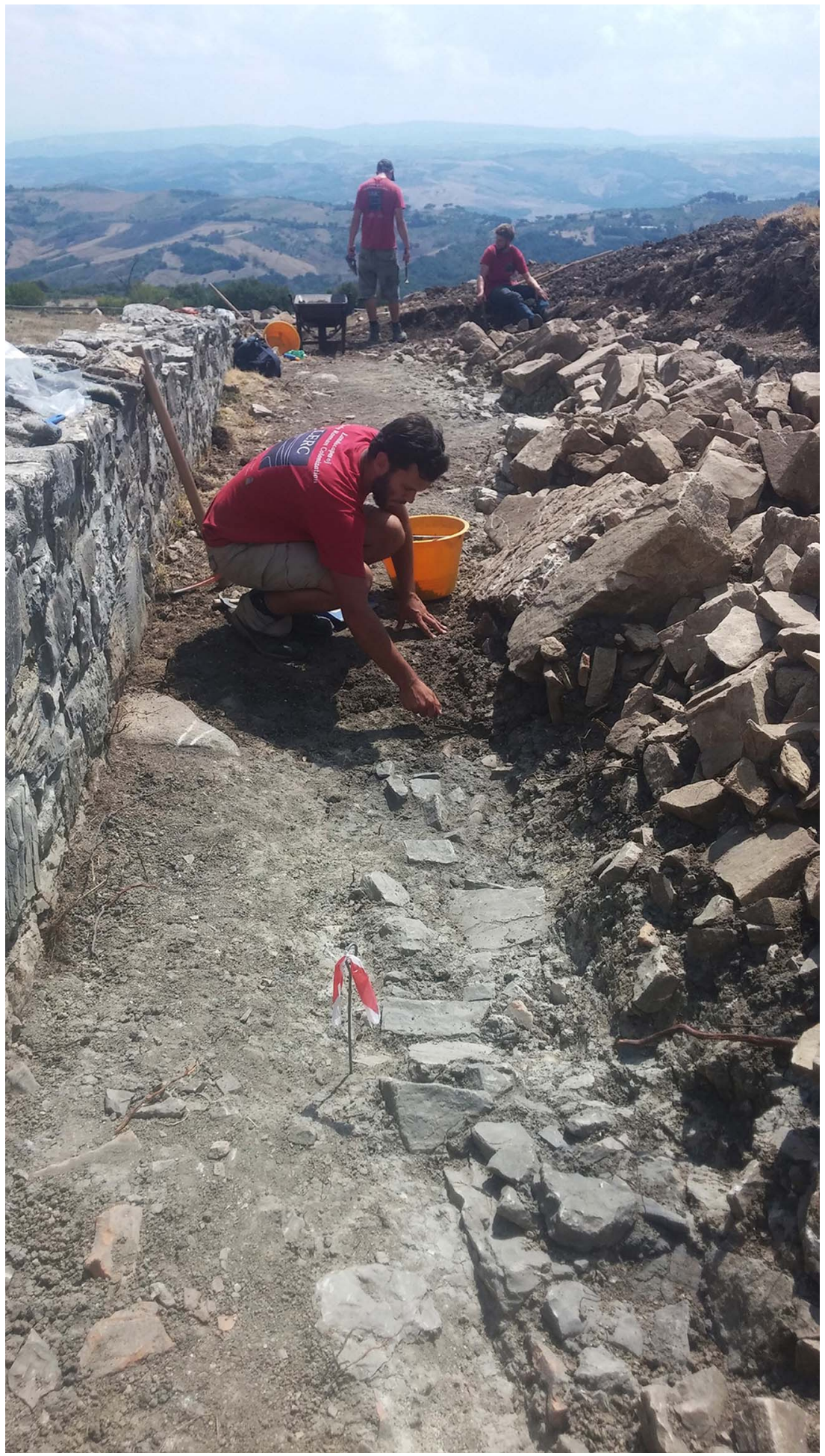

Figure 5. Excavations at the site of Colle Rimontato, San Giovanni in Galdo (image by R. Kalkers).

(C) Antiquity Publications Ltd, 2018 


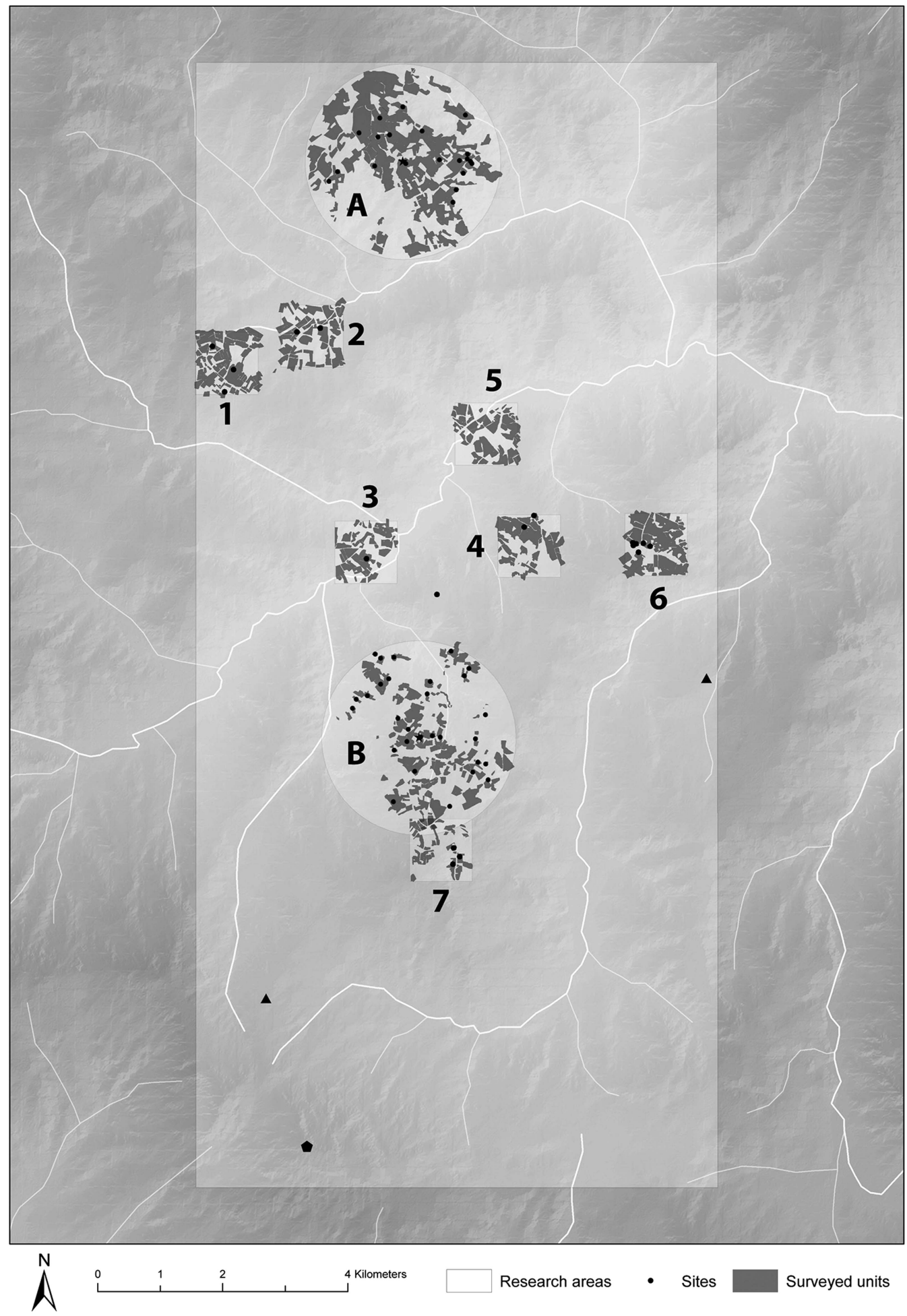

Figure 6. Map of the survey area: A) sanctuary of Colle Rimontato, San Giovanni in Galdo; B) sanctuary of Cupa, Gildone; 1-7) off-site sample areas; 7 corresponds with Montagna di Gildone (image by R. Kalkers).

(C) Antiquity Publications Ltd, 2018 
their chronology (radiocarbon) and their correlation with finds from other sites revealed by the landscape surveys around the two excavated sites (Figure 5).

This study is supplemented by expert revision of the local ceramic typologies and chronologies using TAAP as well as legacy data, applying various techniques (e.g. XRF). Together, the project reveals a rich archaeological landscape, particularly dense with Hellenistic and early Roman settlements clustered on hill plateaus (Figure 6). We are working towards a greater understanding of non-urban settlement organisation in the tumultuous Classical/Hellenistic and Roman periods, with growing precision and less destructive detection and documentation methods.

\section{Acknowledgements}

I would like to thank the Soprintendenza Archeologia del Molise and the municipalities of Jelsi, Gildone and San Giovanni in Galdo for our collaborations, leading to the Centro Didattico Internazionale di Studi Archeologici di Jelsi (CeDISA). I sincerely thank the numerous participants.

\section{References}

Alcock, S.E. \& J.F. Cherry. (ed.) 2004. Side-byside survey. Comparative regional studies in the Mediterranean. Oxford: Oxbow.

Attema, P., G.J. Burgers \& M. Van Leusen. 2011. Regional pathways to complexity. Amsterdam: Amsterdam University Press.

BARKER, G. (ed.). 1995. A Mediterranean valley: landscape archaeology and annales history in the Biferno Valley. Leicester: Leicester University Press.

Bowes, K., K. Francis \& R. Hodges (ed.). 2006. Between text and territory: survey and excavations in the Terra of San Vincenzo Al Volturno. Rome: British School at Rome.

Dench, E. 1995. From barbarians to new men. Oxford: Oxford University Press.

Di Niro, A. \& P.P. Petrone. 1993. Insediamenti di epoca sannitica nel territorio circostante la valle del torrente Tappino. Papers of the British School at Rome 61: 7-49.

https://doi.org/10.1017/S0068246200009922
Foster, B.O. 1922. Livy: History of Rome (volume IV, books 8-10). Boston (MA): Harvard University Press.

Morgan, C. 2003. Early Greek states beyond the polis. London: Taylor \& Francis.

OAKLEY, S.P. 1997. A commentary on Livy: books VI-X. Oxford: Oxford University Press.

Pelgrom, J. \& T.D. Stek. 2010. A landscape archaeological perspective on the functioning of a rural cult place in Samnium. Journal of Ancient Topography 20: 41-102.

STEK, T.D. 2009. Cult places and cultural change in Republican Italy. Amsterdam: Amsterdam University Press.

Stek, T.D., E. Modrall, R.A.A. Kalkers, R.H. Van Otterloo \& J. Sevink. 2015. An early Roman colonial landscape in the Apennine mountains: landscape archaeological research in the territory of Aesernia (central-southern Italy). Analysis Archaeologica 1: 229-82. 